\title{
Comparative effects of barley feed and sodium selenite on selenium levels in hen eggs and tissues
}

\author{
E. KÄÄNTEE and P. KURKELA \\ 66270 Pörtom, Finland
}

\begin{abstract}
An investigation was made into the effects of barleys with varying levels of selenium, and of sodium selenite, on the selenium content of organs in laying hens (blood, spleen, breast muscle, liver, kidney, lung, heart, gizzard and ovary) and in the yolks and whites of their eggs.

The results indicated that grain Se affects the Se level of organs far more than sodium selenite supplementation. The Se concentrations of feed and organs correlate logarithmically, and blood $\mathrm{Se}$ in hen is the most reliable indicator of the Se level in other organs.

It was typically observed that while variations in grain Se caused similar changes in the Se level of both egg yolk and white, sodium selenite primarily affected the yolk Se level. This contrasting effect is similar to that found in earlier published reports
\end{abstract}

\section{Introduction}

Conditions in poultry due to selenium or vitamin E deficiency, or both are encephalomalacia, exudative diathesis and muscular dystrophy. Other lesions are atrophy of the pancreas and fertility disturbances. Selenium deficiency in poultry is not likely to occur under field conditions, though outbreaks have been reported in areas with low grain selenium (JENKINs and Hidiroglou 1971).

Selenium poisoning in livestock takes the from of alkali disease following excessive intake of protein-bound selenium from grains or plants, and chronic selenosis due to selenite or selenate compounds in experimental diets. Symptoms of poisoning are bleeding, oedema, toxic hepatic dystrophy and liver cirrhosis, and nephritis and nephrosis (BERSCHNEIDER et al. 1977). Toxic symptoms in hens are rare. LATSHAw and ORT (1977) showed that $5 \mathrm{mg}$ of selenium (from sodium selenite) per $\mathrm{kg}$ of laying diet had no significant effect on hens.

In plants such as wheat most of the selenium is incorporated into protein as selenomethionine (OLSON et al. 1970), while in selenium accumulator plants it is in the form of selenocystathionine and selenium methylselenocysteine (SHRIFT 1969). The selenium of wheat, fish meal and soybean meal produces considerably higher tissue levels of selenium in chicks and poults than equivalent amounts of sodium selenite (ScotT and THompson 1971). Selenium of plant 
origin was retained more effectively in the tissues of lambs, especially in muscle, than the selenium of selenate (EHLING et al. 1967), which was due to the high urinary excretion of selenium as selenite. Overdosing with selenium as sodium selenite $(1.2 \mathrm{ppm})$ did not cause accumulation of toxic levels of the element in the tissues of swine (LINDBERG and LANNEK 1965). There are correlations between dietary selenium levels and the selenium content of animal tissues (Allaway 1973, KäÄnteE et al. 1978).

Selenium deficiency may occur in plants on selenium deficient and/or acid soils (CARY and Allaway 1969). The general selenium deficiency in Finnish feeds has led to the custom of adding Secontaining mineral supplements to diets and the use of appropriate soil fertilisers. In the present investigation the effects of different batches of grain and sodium selenite supplement, on the Se content of hen eggs and tissues will be evaluated.

\section{Material}

Leghorn hens (P 25) aged 18 months and with a laying percentage of 55 were divided into 6 trial groups $(\mathrm{I}-\mathrm{VI})$ of 15 birds. The hens were kept three to a cage and supplied with drinking water (via nipples) and food in feed troughs twice per day. Eggs were collected once daily.

The trial feed mixtures supplied to each group consisted of $600 \mathrm{~g}$ of whole oats, $250 \mathrm{~g}$ of concentrate, $1.000 \mathrm{~g}$ of barley meal per day and cruset limistone ad. lib.

Fertiliser applied during the cultivation of the barley contained varying amounts of Se supplement. Eour batches of barley (lots I-IV) differing in selenium content were available from different sections of the same field.

Hen groups I, V and VI received barley from lot I. Test groups V and VI were additionally given sodium selenite (SElvet, Orion) daily. Table 1 gives the analysed Se concentrations of the components used in the feed, the amounts of sodium selenite added and, on this basis, the Se concentration of the feed. The table also includes the analysed selenium concentrations of feed samples taken from feed troughs.

Prior to the actual feeding trial all test groups were placed for a two-week period on diet number I (Table 1).

The composition of the concentrate is given in Table 2 .

Table 1. The analysed Se concentrations of the barley, oats and concentrate in the feed supplied to the test groups; the amounts of sodium selenite supplement; the calculated and analysed feed Se content. $\mathrm{Mg} / \mathrm{kg}$ dry matter.

\begin{tabular}{|c|c|c|c|c|c|c|}
\hline \multirow{2}{*}{$\begin{array}{r}\text { Se content } \\
\mathrm{mg} / \mathrm{kg}\end{array}$} & \multicolumn{5}{|c|}{ Test groups } & \multirow[b]{2}{*}{ VI } \\
\hline & I & II & III & IV & V & \\
\hline Barley ............................ & 0.01 & 0.17 & 0.68 & 1.0 & 0.01 & 0.01 \\
\hline 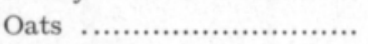 & 0.01 & 0.01 & 0.01 & 0.01 & 0.01 & 0.01 \\
\hline Concentrate...$\ldots \ldots \ldots \ldots \ldots \ldots$ & 0.7 & 0.7 & 0.7 & 0.7 & 0.7 & 0.7 \\
\hline Sodium selenite suppl. .... & - & - & - & - & 1.0 & 2.0 \\
\hline Calculated Se conc. ......... & 0.1 & 0.19 & 0.47 & 0.64 & $\begin{array}{l}1.2 \\
0.1+1.1\end{array}$ & $\begin{array}{l}2.2 \\
0.1+2.1\end{array}$ \\
\hline Analysed Se conc. .......... & 0.06 & 0.1 & 0.5 & 0.7 & 1.3 & 2.0 \\
\hline
\end{tabular}




$\begin{array}{lrll}\text { Fat-free milk powder } & 12 \% & \text { Calcium phosphate } & 4.8 \% \\ \text { Fish meal } & 30 \% & \text { Hostaphos } & 0.8 \% \\ \text { Soybean grist } & 26.2 \% & \text { Table salt } & 1.5399 \% \\ \text { Turnip rape grist } & 4.0 \% & \text { Magnesium oxide } & 0.4230 \% \\ \text { Meat-bone meal } & 4.5 \% & \text { Copper oxide } & 0.0127 \% \\ \text { Fodder yeast } & 5.0 \% & \text { Iron sulphate } & 0.1025 \% \\ \text { Molasses } & 1.0 \% & \text { Copper iodide } & 0.0009 \% \\ \text { Alfalfa meal } & 6.5 \% & \text { Zinc oxide } & 0.0384 \% \\ \text { Vitamin mixture } & 3.0 \% & \text { Manganese oxide } & 0.0820 \% \\ & & \text { Cobalt sulphate } & 0.006 \%\end{array}$

\section{Methods}

Egg yields of the groups during the pre-trial feeding period and the actual test period were recorded. The duration of the trial was 28 days and 6 eggs were collected every seven days from each group for selenium analysis which was performed on yolk and white fractions separately. The Se content of droppings was also analysed weekly. In addition, the hens received a weekly clinical examination.

After 28 days 6 hens from each group were slaughtered. Samples were taken from 9 tissues for Se determinations viz. blood, breast muscle, liver, spleen, lung, kidney, ovary, heart and qizzard. These organs were examined macroscopically.

The remaining hens in groups IV and VI were transferred back to diet 1, and 4 eggs subsequently collected from both groups twice weekly for Se analyses.

The Se concentrations of feeds, eggs, organs and droppings were determined at the Oulu Research Laboratory of Kemira company. The method employed was SAARI and PAaso's (1979) modification of the Siemer and HagemanN (1975) hydride method, the former having been developed in this laboratory. The lowest measurable content by this method is $10 \mu \mathrm{g} / \mathrm{kg}$.

The following methods were used in the statistical analysis of the results:

- For the establishment of differences between groups on different diets one-way variance analysis and SNK modification of the Tukey's test were employed.

- The correlation between the Se concentration of feed and tissues was tested by means of regression analysis, with the feed Se concentration as systematic variable. Analysis was made for logarithmic function and linear model.

- The correlations between the selenium concentrations of different parts of the body were expressed as correlation coefficients between two random variables.

- Similarity in effect of grain Se and sodium selenite was clarified by means of one-way variance analysis and SNK modification of the Tukey's test.

\section{Results}

During the two-week pre-trial feeding period with diet number 1 the egg yield from all test groups was similar. During the actual trial the egg yield from group VI fell below that of the other groups (Table 3). Great variation was found in the Se concentration of droppings in the weekly analyses between 
different groups, with values ranging from $0.02 \mathrm{mg} / \mathrm{kg}$ to $1.2 \mathrm{mg} / \mathrm{kg}$ (Table 4 ). The results of the analyses at week 4 were close to the feed Se concentrations (Table 1).

Table 3. Weekly egg yield of trial groups during two-week pretrial feeding period (Ie and IIe) and four-week trial period.

\begin{tabular}{ccccccc}
\hline Week & I & II & III & IV & V & VI \\
\hline I e & 48 & 47 & 49 & 50 & 48 & 51 \\
II e & 51 & 52 & 51 & 49 & 53 & 52 \\
\hline 1 & 50 & 50 & 48 & 50 & 43 & 46 \\
1 & 50 & 55 & 43 & 56 & 49 & 42 \\
3 & 59 & 1 & 53 & 56 & 58 & 40 \\
4 & 48 & 57 & 47 & 57 & 60 & 46 \\
\hline
\end{tabular}

Table 4. The Se concentrations of droppings at the beginning and during the test, $\mathrm{mg} / \mathrm{kg}$ dry matter.

\begin{tabular}{cllllll}
\hline Week & I & II & III & IV & V & VI \\
\hline 0 & 0.15 & 0.06 & 0.1 & 0.15 & 0.05 & 0.04 \\
1 & 0.03 & 0.04 & 0.35 & 0.35 & 0.04 & 0.01 \\
2 & 0.09 & 0.5 & 0.6 & 0.6 & 1.2 & 1.4 \\
3 & 01 & 0.3 & 0.7 & 0.5 & 0.7 & 1.6 \\
4 & 0.02 & 0.16 & 0.46 & 0.78 & 1.2 & 1.7 \\
\hline
\end{tabular}

The Se content of eggs at the beginning of the trial was found to be $85 \pm$ $36 \mu \mathrm{g} / \mathrm{kg}$ dry matter $(28 \pm 11 \mu \mathrm{g} / \mathrm{kg}$ for white and $170 \pm 70 \mu \mathrm{g} / \mathrm{kg}$ for yolk). Thereafter the Se concentration increased rapidly in groups II-VI over a $2-3$ week period, stabilizing at the level of week 4 (Figure 1).

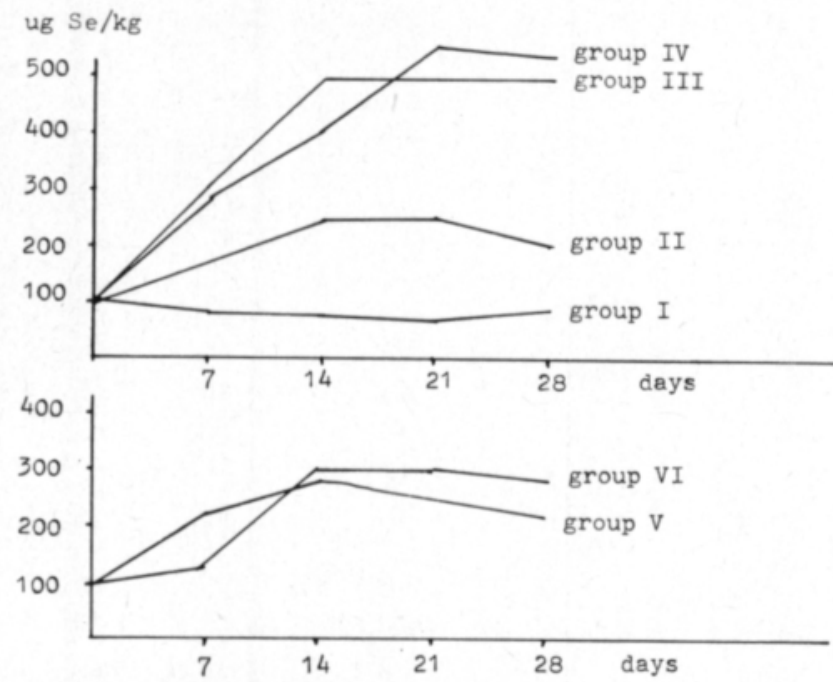

Fig. 1. Effect of selenium content of feed on that of eggs in different trial groups during the trial. 
The Se concentrations of egg white, yolk and whole eggs are presented in Table 5. After 28 days some of the hens from groups IV and VI were switched back to diet 1 , whereafter the Se content of yolk and white rapidly decreased (Table 6, Figures 2 and 3).

Table 5. The Se content of white, yolk and whole egg after 28 days, $\mu \mathrm{g} / \mathrm{kg}$.

\begin{tabular}{lrrr}
\hline Group & White & Yolk & Whole egg \\
\hline I & $17 \pm 5$ & $130 \pm 25$ & $50 \pm 10$ \\
II & $76 \pm 11$ & $330 \pm 73$ & $160 \pm 26$ \\
III & $423 \pm 75$ & $670 \pm 65$ & $493 \pm 68$ \\
IV & $440 \pm 50$ & $898 \pm 49$ & $588 \pm 22$ \\
V & $63 \pm 27$ & $533 \pm 110$ & $222 \pm 57$ \\
VI & $125 \pm 45$ & $655 \pm 192$ & $312 \pm 77$ \\
\hline
\end{tabular}

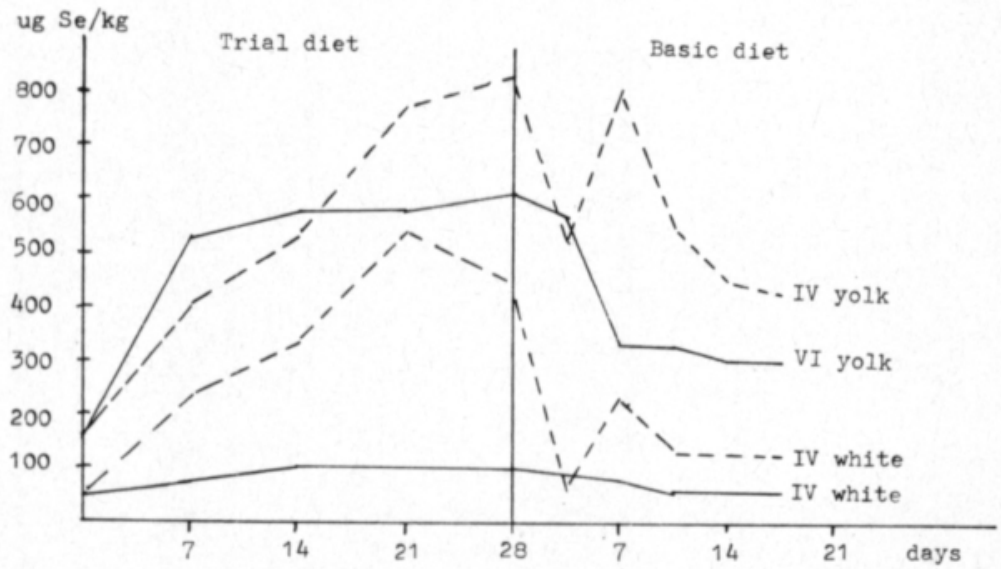

Fig. 2. Selenium content (ug/kg dry matter) of eggs in trial groups IV and VI during the trial and after transfer back to the basic diet.

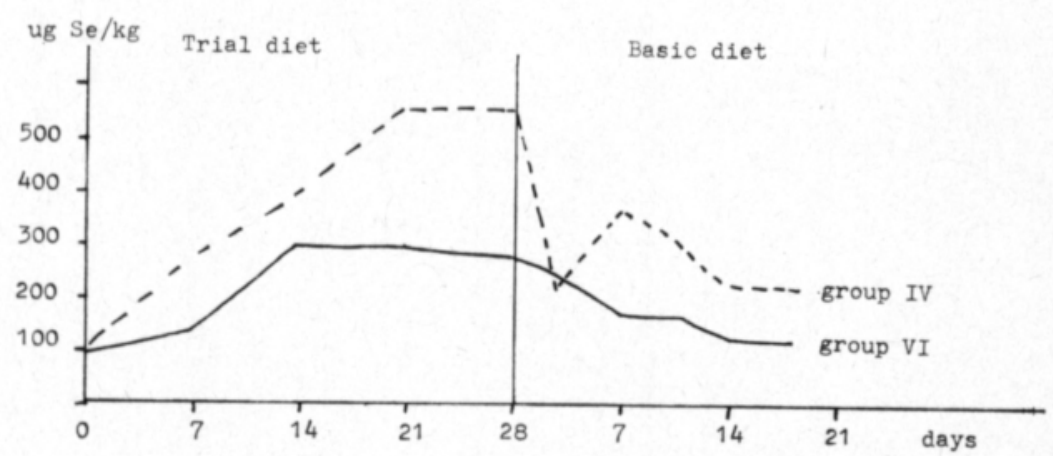

Fig. 3. Selenium content of egg yolk and white in trial groups IV and VI during the trial and basic diet period. 
Table 6. Changes in Se concentrations of white, yolk and whole egg in groups IV and VI after transfer back to basic diet, $\mu \mathrm{g} \mathrm{Se} / \mathrm{kg}$ dry matter.

\begin{tabular}{|c|c|c|c|c|c|c|}
\hline \multirow[t]{2}{*}{ Time } & \multicolumn{3}{|c|}{ Group IV } & \multicolumn{3}{|c|}{ Group VI } \\
\hline & White & Yolk & Whole & White & Yolk & Whole \\
\hline 0 & $440 \pm 50$ & $898 \pm 49$ & $588 \pm 22$ & $125 \pm 45$ & $655 \pm 192$ & $312 \pm 77$ \\
\hline 4 & $55 \pm 73$ & $538 \pm 73$ & $214 \pm 34$ & $85 \pm 13$ & $572 \pm 112$ & $244 \pm 51$ \\
\hline 7 & $235 \pm 38$ & $685 \pm 26$ & $382 \pm 13$ & $45 \pm 10$ & $333 \pm 25$ & $140 \pm 8$ \\
\hline 11 & $125 \pm 31$ & $548 \pm 59$ & $269 \pm 31$ & $55 \pm 13$ & $342 \pm 33$ & $145 \pm 17$ \\
\hline 14 & $108 \pm 26$ & $450 \pm 38$ & $221 \pm 18$ & $48 \pm 10$ & $305 \pm 51$ & $131 \pm 19$ \\
\hline 18 & $115 \pm 6$ & $440 \pm 85$ & $217 \pm 22$ & $43 \pm 5$ & $307 \pm 67$ & $130 \pm 22$ \\
\hline
\end{tabular}

Table 7. Means and standard deviations of Se concentrations $(\mu \mathrm{g} / \mathrm{kg}$ dry matter) in blood, spleen, muscle, liver, kidney, lung, heart, gizzard and ovary of the trial groups.

\begin{tabular}{|c|c|c|c|c|}
\hline \multirow{2}{*}{\multicolumn{2}{|c|}{ Trial group }} & Blood & Spleen & Muscle \\
\hline & & Mean \pm S D. & Mean \pm S D. & Mean \pm S D. \\
\hline \multirow{8}{*}{\multicolumn{2}{|c|}{ Trial group }} & $282 \pm 134$ & $1097 \pm 178$ & $112 \pm 39$ \\
\hline & & $792 \pm 139$ & $1567 \pm 259$ & $277 \pm 44$ \\
\hline & & $1753 \pm 103$ & $1963 \pm 279$ & $575 \pm 155$ \\
\hline & & $1896 \pm 461$ & $1903 \pm 407$ & $538 \pm 143$ \\
\hline & & $1171 \pm 227$ & $1372 \pm 292$ & $220 \pm 33$ \\
\hline & & $1205 \pm 136$ & $1578 \pm 234$ & $335 \pm 67$ \\
\hline & & Liver & Kidney & Lung \\
\hline & & Mean \pm S D. & Mean \pm S.D. & Mean \pm S.D. \\
\hline \multirow{14}{*}{ Trial } & I & $550 \pm 208$ & $1287 \pm 348$ & $402 \pm 77$ \\
\hline & II & $1035 \pm 139$ & $1678 \pm 241$ & $752 \pm 50$ \\
\hline & III & $1548 \pm 179$ & $2630 \pm 340$ & $1867 \pm 153$ \\
\hline & IV & $1770 \pm 422$ & $3862 \pm 646$ & $1912 \pm 379$ \\
\hline & V & $1280 \pm 208$ & $3158 \pm 271$ & $1278 \pm 202$ \\
\hline & VI & $1708 \pm 545$ & $3340 \pm 215$ & $1560 \pm 237$ \\
\hline & group & Heart & Gizzard & Ovary \\
\hline & g.0ति & Mean \pm S.D. & Mean \pm S.D. & Mean \pm S.D. \\
\hline & I & $285 \pm 54$ & $390 \pm 78$ & $297 \pm 73$ \\
\hline & II & $567 \pm 48$ & $813 \pm 79$ & $828 \pm 328$ \\
\hline & III & $1113 \pm 110$ & $1797 \pm 161$ & $1540 \pm 168$ \\
\hline & IV & $1240 \pm 290$ & $2022 \pm 444$ & $1608 \pm 275$ \\
\hline & V & $675 \pm 44$ & $978 \pm 138$ & $1323 \pm 310$ \\
\hline & VI & $745 \pm 63$ & $888 \pm 86$ & $1442 \pm 280$ \\
\hline
\end{tabular}

The observed variation in egg Se levels was uniform to the extent that grain Se caused increases in the Se concentration of both yolk and white whereas sodium selenite mainly affected only the yolk Se level.

The Se concentrations the organs of hens slaughtered after 28 days are presented in Table 7. 
During the trial period the hens were clinically healthy, and macroscopic examination of the organs after slaughter brought to light no evidence of abnormalities.

Analysis of the results indicates that the Se concentration of feed highly significantly affected the Se content of tissues in the hens investigated, i.e. an increase in the selenium content of the feed was associated with an increase in tissue selenium concentrations. This correlation was logarithmic - when the selenium concentration of the feed was low a slight increase caused a considerable corresponding rise in the selenium content of the tissues. The greater the selenium content of the feed, the smaller was the corresponding increase in tissue selenium levels. Selenium derived from grain produced a more marked effect than sodium selenite supplementation.

Changes in the selenium content of blood, lung, heart, spleen and muscle were comparable, and differed considerably from those observed in kidney and liver. Sodium selenite increased the renal Se concentration very markedly. Table 8 shows the correlations between different parts of the body.

The blood selenium concentration provides the most reliable indicator of selenium levels in the hen. Changes occurring in body selenium appear to be greatest in the kidney and least in muscle.

It was shown statistically that when feed containing $60 \mu \mathrm{g} \mathrm{Se} / \mathrm{kg}$ plus a sodium selenite supplement of $1940 \mu \mathrm{g} \mathrm{Se} / \mathrm{kg}$ are mixed in the diet, the effect on selenium levels in the hen is of the same order as that produced by a diet containing $500 \mu \mathrm{g} \mathrm{Se} / \mathrm{kg}$ from grain as a sole source of selenium.

Grain selenium has a far more powerful influence than sodium selenite on the Se level of tissues.

\section{Discussion}

During the trial no changes were observed in the clinical condition of the hens, which leads to the conclusion that their health was unaffected by the feed given. The lowest Se concentration of $0.06 \mathrm{mg} / \mathrm{kg}$ was close to the generally accepted requirement level for animals of $0.1 \mathrm{mg} / \mathrm{kg}$ and exceeded the minimum requirement level of $0.05 \mathrm{mg} / \mathrm{kg}$ arrived at by LAtshaw and ORT (1977). Moreover, the highest Se concentration of $2 \mathrm{mg} / \mathrm{kg}$ employed was substantially lower than the $5.0 \mathrm{mg} / \mathrm{kg}$ used by LATSHAw and ORT in their experiments, which was found to cause no significant changes in hens. The only noteworthy occurrence in this respect was the low egg yield in the group receiving the most sodium selenite.

The weekly variation in Se content of droppings (Table 4) was considerable. This is considered to result from variations in the composition of droppings and the fact that feed was scattered outside the feed troughs.

The paucity of Se in Finnish feed and eggs was apparent when the results were compared with those of ScoTT and THOMPSON (1977), who reported that hens on feed containing the basic nutritional requirement of $0.1 \mathrm{mg} \mathrm{Se} / \mathrm{kg}$ had a mean egg yolk Se concentration of $0.184 \mathrm{mg} / \mathrm{kg}$ and an egg white concentration of $0.05 \mathrm{mg} / \mathrm{kg}$. LATSHAw and Osman (1975) report a value of 0.25 $\mathrm{mg} / \mathrm{kg}$ for both yolk and white. According to Scotr and Thompson the Se 
concentration of German eggs is $1.0 \mathrm{mg} / \mathrm{kg}$, while on the west coast of the United States it is $0.35 \mathrm{mg} / \mathrm{kg}$. In the present investigation, hens on the basic diet initially had a yolk Se concentration of $170 \pm 70 \mu \mathrm{g} / \mathrm{kg}$, a white level of $28+11 \mu \mathrm{g} / \mathrm{kg}$ and a whole egg concentration of $85+36 \mu \mathrm{g} / \mathrm{kg}$. These values are low in comparison to those previously recorded, and the Se content of eggs from group IV $(588 \pm 22 \mu \mathrm{g} / \mathrm{kg}$ ) during the trial (Table 5, Figure 1) was well below that found in German eggs.

In quail supplied with feed composed of $60 \%$ wheat having a Se concentration of $5.7 \mathrm{ppm}$, egg yolk had a Se concentration of $3 \mathrm{ppm}$ and white of $10 \mathrm{ppm}$ (Stoewsand et al. 1978). Values for organs were: heart $4.4 \pm 0.7$ ppm, kidney $9.5 \pm 1.1 \mathrm{ppm}$, liver $12.7 \pm 2.4 \mathrm{ppm}$ and muscle $4.1 \pm 0.6 \mathrm{ppm}$. The quail were healthy and the enzymatic activity of their liver microsomes did not deviate from that of the control group.

In the investigated material, grain Se raised the Se concentration of egg yolk and white similarly, while almost all of the rise due to sodium selenite occurred in the yolk (Tables 5 and 6, Figure 3). This finding supports the observations of LATSHAW and OSman (1975), that "when selenium from practical feedstuffs was fed, the selenium content of dried egg white was about equal to or greater than the selenium content of dried egg yolk. When selenite was fed the selenium content of dried yolk was higher." According to the same authors, selenocysteine has a similar effect to selenite on the Se content of egg yolk. In all groups studied during the present trial the Se concentration of yolk was greater than that of white. This is considered to result from the concentrate which was fed; Se compounds present in such concentrate formulas behave in the body in a similar manner to selenocysteine and selenite in raising the Se content of yolk higher than that of white.

After transfer back to the basic diet, the Se content of both yolk and white in eggs of group IV hens initially fell sharply, before rising and then finally declining slowly back to the base level. The sharp drop after the change of diet is considered to be due to the slow mobilization of selenium-methionine bound to hen protein. No corresponding transient phenomenon was noted in the sodium selenite group (VI).

According to ScotT and Thompson (1971), the Se content of liver and musculature of hens on a diet fulfilling the norms are 1.5 and $0.4 \mathrm{mg} / \mathrm{kg}$ of dry matter. The results from trial feed III in this investigation are in agreement with these values (Table 7). The Se content of both hens and eggs in the basic diet group remained significantly below values recorded in the literature, indicating the paucity of Se in the feed. Statistical analysis of the relationships between the Se concentration of tissues and the Se content of feed revealed grain Se to influence tissue levels to a much greater extent than sodium selenite. During elimination, the latter has been shown to increase kidney Se concentration significantly (LINDBERG and LANNEK 1965).

SIMENSEN et al. (1979) state that the correlation between Se in plasma, liver and musculature is very close, and that the Se concentration of blood and tissues reflects the level of dietary Se. This also became apparent in the present trial, where blood was shown statistically to be the best indicator of Se status in the hen. 
The Se concentrations of organs from different groups indicated that grain Se has a more powerful influence than sodium selenite on the Se level of the body. It was shown statistically that $500 \mu \mathrm{g}$ of grain Se is biologically equivalent to 4 times that amount of sodium selenite, which is well in accordance with the observations of ScotT and Thompson (1971) and EHLING et al. (1967), who demonstrated selenium of plant origin to raise the body selenium level more effectively than selenium salts.

The relatively low tissue Se concentrations among the groups given sodium selenite compared to those given grain can be seen in Table 7. One noteworthy exception was the kidney, in which selenite caused an increase in selenium concentration. Within both grain and selenite groups correlations were found between the Se concentrations of different organs (Table 8). Most strongly associated in this respect were blod, lung and heart, while kidney and liver correlated poorly with the other organs. These results also supported an observation of SIMENSEN et al. (1979) that the selenium concentration of heart muscle was approximately half that of liver.

The following conclusions can be drawn on the basis of these trial results:

- grain Se has a greater effect than sodium selenite on the selenium concentration of the body

- grain Se increases the selenium level of both egg yolk and white, while sodium selenite mainly increases only yolk Se

- blood selenium concentration is the best indicator of the selenium level of the body

- a grain Se concentration of $0.7 \mathrm{mg} / \mathrm{kg}$ did not adversely affect the health of hens.

\section{Summary}

During the tests six 15-hen groups were supplied over a 28-day period with feed containing the following concentrations of Se:

- I $0.06 \mathrm{mg} / \mathrm{kg}$

- II $0.1 \mathrm{mg} / \mathrm{kg}$

- III $0.5 \mathrm{mg} / \mathrm{kg}$

- IV $0.7 \mathrm{mg} / \mathrm{kg}$

- V $0.06 \mathrm{mg} / \mathrm{ka}+1.2 \mathrm{mg} \mathrm{Na} \mathrm{SeO}_{3}$

- VI $0.06 \mathrm{mg} / \mathrm{kg}+2 \mathrm{mg} \mathrm{Na} \mathrm{SeO}_{3} / \mathrm{kg}$

During the test period the Se concentration of eggs from groups II - IV increased from the original levels of $85 \pm 36 \mu \mathrm{g} / \mathrm{kg}$ of dry matter to $160 \pm 26$ $\mu \mathrm{g} / \mathrm{kg}$ in group II, $493 \pm 68 \mu \mathrm{g} / \mathrm{kg}$ in group III and $588 \pm 22 \mu \mathrm{g} / \mathrm{kg}$ in group $\mathrm{IV}$, and the increase was in both yolk and white. In groups V and VI only the Se concentration of yolk showed any marked increase, the values for whole eggs after 28 days being $222 \pm 57$ and $312 \pm 77 \mu \mathrm{g} / \mathrm{kg}$ of dry matter, respectively.

After 28 days 6 hens were slaughtered from each group and the Se concentrations in blood, spleen, liver, kidney, lung, ovary, breast muscle, gizzard 
and heart were determined. The Se concentration of feed was shown statistically to have a highly significant correlation with the tissue levels of Se while blood proved the best indicator of Se status of the hens. Corrolations were demonstrated between the Se concentrations of different organs. Grain Se had a greater effect than sodium selenite on the tissue Se levels.

At the end of the trial period the hens of groups IV and VI were switched back to diet 1 resulting initially in a steep drop in the Se concentration of group IV eggs, followed by an increase after 7 days back to the original level and thereafter a gentle fall. The corresponding decline in group VI was steady.

\section{REFERENCES}

Allaway, W. H. 1973. Selenium in the food chain. Cornell, Veter. 63:151-170.

Berschneider, F., Hess, M., Neuffer, K. \& Willer, S. 1977. Untersuchungen über die Verträglichkeit und Toxizität von Luzernegrünmehl-Pellets nach Selendüngung. Arch. Tierernähr. 27: 737-744.

Cary, E. E. \& Allaway, W. H. 1969. Stability of different forms of selenium applied to low level soils. Soil Sci. Soc. Amer., Proc. 33: 571-574.

Ehling, C. F., Hogue, D. E., Allaway, W. H. \& Hamm, D. J. 1967. Fate of selenium from selenite or seleno-methionine with or without vitamin $\mathrm{E}_{1}$ in lambs. J. Nutr. 92: 121126.

Jenkins, K. J. \& Hidiroglou, M. 1972. Comparative metabolism of $\left({ }^{75} \mathrm{Se}\right)$-selenite, $\left({ }^{75} \mathrm{Se}\right)$ -selenate and $\left({ }^{75} \mathrm{Se}\right)$-seleno-methionine in bovine erythrocytes. Can. J. Anim. Sci. 52: $591-20$.

KäÄntee, E., Kurkela, P. \& Korhonen, I. 1978. The blood selenium content of Finnish warmblood trotters. Suom. Eläinlääk. 1. 84: 393-397.

Latshaw, J. P. \& Diesem, C. D. 1977. Toxic levels of selenium from sodium selenite in laying diets. Poult. Sci. 56: 1729-1730.

- , Ort, J. E. \& Diesem, C. D. 1977. The selenium requirements of the hen and effects of a deficiency. Poult. Sci. 56: 1876-1881.

- , Osman, M. 1975. Distribution of selenium in egg white and yolk after feeding natural and synthetic selenium compounds. Poult. Sci. 54: 1244-1252.

LindBerg, P. \& LANNeK, N. 1965. Retention of selenium in kidneys, liver and striated muscle after prolonged feeding of therapeutic amounts of sodium selenite to pigs. Acta Veter. Scand. 6: $217-223$.

Olson, O. E. Novacek, E. J., Whitehead, E. J. \& Palmer, I. S. 1970. Selenium in wheat. Phytochem. 9: 1181-1188.

SAARI, E. \& PAaso, M. 1979. Personal communication.

Scotr, M. L. \& Thompson, J. N. 1971. Selenium content of feedstuffs and effects of dietary selenium levels upon tissue selenium in chicks and poults. Poult. Sci. 50: 1742-1748.

Shrift, A. 1969. Aspects of selenium metabolism in higher plants. Ann. Rev. Pl. Physiol. 20: 475-494,

Stemer, D. D. \& Hagemann, L. 1975. An improved hydride generationatomic absorption apparatus for selenium determinatiln. Anl. Lett. 8: 233-327.

Simensen, M. G., Nielsen, N. E., Danielsen, V., Gissel-Nielsen, G., Hyarde, W., Leth, T. \& BASSE, A. 1979. Selenium and vitamin E deficiency in pigs. Acta Veter. Scand. 20: $289-305$.

Stoewsand, G. S., Gutermann, W. H. \& Lisk, D. J. 1978. Wheat grown on fly ash: High selenium uptake and response when fed to Japanese quail. J. Agric. Food Chem. 26: $757-759$.

Ms received March 11, 1980. 


\title{
Rehun seleenipitoisuuden vaikutuksista kananmunien ja kanan elimistön seleenipitoisuuteen
}

\author{
Esa KäÃntee ja PaAvo Kurkeca \\ 66270 Pörtcm
}

Tutkimuksessa ruokittiin kuutta 15 kanan ryhmää 28 vrk:n ajan rehulla joiden Se pitoisuudet olivat:

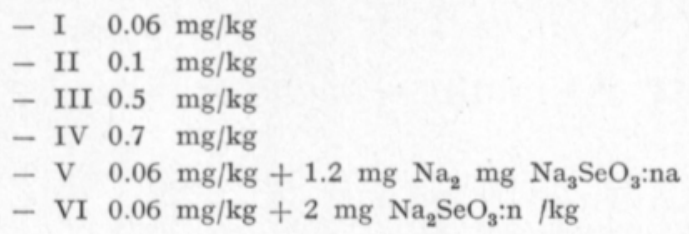

Ruokinnan aikana ryhmien II-IV munien Se-pitoisuudet kohosivat alkutasostaan $85 \pm 36$ ug/kg kuiva-ainetta, ryhmällä II $160 \pm 26 \mathrm{ug} / \mathrm{kg}$, ryhmällä III $493 \pm 68 \mathrm{üg} / \mathrm{kg}$ ja ryhmällä IV $588 \pm 22 \mathrm{ug} / \mathrm{kg}$. Sekä keltuaisen että valkuaisen Se-taso nousi. Ryhmissä V VI nousi pääasiassa vain keltuaisten Se-pitoisuudet koko munien Se-pitoisuuksien ollessa 28 vrk:n kuluttua $222 \pm 57 \mathrm{ug} / \mathrm{kg}$ ja $312 \pm 77 \mathrm{ug} / \mathrm{kg}$.

28 vrk:n kuluttua teurastettiin joka ryhmästä 6 kanaa. Kanojen veren, pernan, maksan, munuaisten, keuhkojen, munasarjojen, rintalihasten, lihasmahan ja sydämen Se- pitoiduuset määritettiin. Rehun Se-pitoisuuden todettiin vaikuttavan tilastollisesti vakavasti merkitsevästi tutkittujen elinten Se-pitoisuuksiin. Veren Se-pitoisuus kuvasti parhaiten kanan Sepitoisuutta. Eri elinten Se-pitoisuudet korreloivat keskenåän. Viljan Se vaikutti natriumseleniittiä voimakkaammin elimistön Se-pitoisuuteen.

Koeajkson loputtua ryhmien IV ja VI kanat siirrettiin ruokinnalle 1. Tällöin todettiin ryhmällä IV munien Se-pitoisuudessa aluksi jyrkkä lasku. Se-pitoisuus kohosı 7 vrk:n kuluttua lähelle alkutasoaan ja laski sitten loivasti. Ryhmällä VI lasku oli tasainen. 